\title{
Atmospheric precipitation as a source of biogenic elements entering the ecosystem of Lake Baikal
}

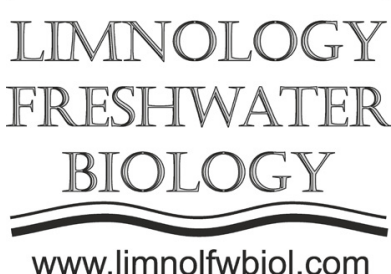

\author{
Obolkin V.A.*, Khodzher T.V., Netsvetaeva O.G. \\ Limnological Institute, Siberian Branch of the Russian Academy of Sciences, Ulan-Batorskaya Str., 3, Irkutsk, 664033, Russia
}

ABSTRACT. The average long-term ratios of biogenic elements in atmospheric precipitation and the surface layer of lake water in the cold and warm seasons are analysed. It is shown that the role of atmospheric precipitation in the formation of primary lake production may be underestimated. Directions for more detailed research of the role of atmospheric nitrogen and phosphorus inputs in the functioning of the lake ecosystem are proposed.

Keywords: atmospheric deposition, lakewater chemistry, biogenic elements

Primary production of aquatic ecosystems is limited mainly by two factors: the presence of biogenic chemical compounds and the influx of solar radiation. The income of solar radiation is determined by the climate of the region and is usually well studied. Less clear are the factors that determine the dynamics of biogenic elements in the layer where photosynthesis occurs. It is known that nitrogen, phosphorus, and silicon compounds can limit the development of algae in Lake Baikal (Kozhov, 1962). The main sources of biogenic compounds in the upper layers of the lake are considered to be the upwelling from the deeper layers and the river inflow, less attention is paid to the atmosphere. In the lake's water balance, river flow is $82 \%$, and precipitation is $13 \%$. More over the salinity of precipitation is about 10 times lower than that of river water. Therefore, for most of the main ions, the contribution of precipitation to the chemical balance of the lake is even less - from 2 to $6 \%$ (Khodzher and Sorokovikova, 2007). However, if we consider nitrogen and phosphorus compounds separately, the situation is radically different: according to already known estimates (Galazy, 1984; Khodzher and Sorokovikova, 2007), the intake of nitrates and phosphorus with atmospheric precipitation is about $25-30 \%$ of their total balance in the lake. Moreover, unlike river water, these soluble compounds with atmospheric precipitation fall directly into the upper photosynthetic layers of the lake and are therefore more accessible for algae. Therefore, the role of nitrogen and phosphorus from the atmosphere in primary production may be more significant and complicated than the balance sheet estimates suggest.

A short-term outbreak of algae development under the spring ice of Lake Baikal has been known for a long time and, it would seems, has been well studied, but there is still no unambiguous explanation for this phenomenon. The maximum accumulation of algae occurs in a fairly thin layer $(0-2 \mathrm{~m})$ under the ice by mid-April and coincides with the beginning of melting of the snow cover on the ice. In this regard, it has been suggested (Obolkin et al., 2019) that snow water may be one of the main sources of biogenic elements for under ice phytoplankton. Average estimates show that concentrations of nitrates and ammonium in melting snow can be much higher than in the lake's under ice water (Table 1).

The penetration of these compounds through the pores and cracks of spring ice into the water can cause rapid development (perhaps just accumulation) of algae under the ice. In part, the source of high nitrate content in the snow cover of southern Baikal may be the influence of nitrogen oxide emissions from regional coal-fired Power Plants.

The excess of concentrations of biogenic elements in the precipitation of the warm season over their concentration in the Lake Baikal water also

Table 1. Concentrations (mg / l) of major ions in precipitation and in Lake Baikal water. Cold season of 2015-2019 (average).

\begin{tabular}{|c|c|c|c|c|c|c|c|c|c|c|}
\hline & $\mathbf{S O}_{4}{ }^{2-}$ & $\mathbf{N O}_{3}{ }^{-}$ & $\mathbf{C l}^{-}$ & $\mathbf{P O}_{4}{ }^{3-}$ & $\mathbf{N H}_{4}{ }^{+}$ & $\mathbf{N a}^{+}$ & $\mathbf{K}^{+}$ & $\mathbf{C a}^{2+}$ & $\mathbf{M g}^{2+}$ & $\mathbf{p H}$ \\
\hline Precipitation (Listvanka) & 3.50 & 3.04 & 0.23 & 0.03 & 0.42 & 0.21 & 0.24 & 1.43 & 0.19 & 5.31 \\
Lake Baikal water & 5.5 & 0.40 & 0.40 & 0.02 & 0.02 & 3.5 & 0.95 & 16.1 & 3.0 & 7.8 \\
Ratio: precipitation/water & 0.64 & 7.6 & 0.58 & 1.5 & 21 & 0.06 & 0.25 & 0.09 & 0.06 & \\
\hline
\end{tabular}

*Corresponding author.

E-mail address: obolkin@lin.irk.ru (V.A. Obolkin)
(C) Author(s) 2020. This work is distributed under the Creative Commons Attribution 4.0 License. 
Table 2. Concentrations ( $\mathrm{mg} / \mathrm{l}$ ) of major ions in atmospheric precipitation and in the water of Lake Baikal. Warm season of 2015-2019(average).

\begin{tabular}{|c|c|c|c|c|c|c|c|c|c|c|}
\hline & $\mathbf{S O}_{4}{ }^{2-}$ & $\mathbf{N O}_{3}^{-}$ & $\mathbf{C l}^{-}$ & $\mathbf{P O}_{4}{ }^{-}$ & $\mathbf{N H}_{4}^{+}$ & $\mathbf{N a}^{+}$ & $\mathbf{K}^{+}$ & $\mathbf{C a}^{2+}$ & $\mathbf{M g}^{2+}$ & $\mathbf{p H}$ \\
\hline Precipitation (Listvanka) & 2.46 & 1.10 & 0.20 & 0.03 & 0.48 & 0.08 & 0.15 & 0.51 & 0.08 & 4.89 \\
Lake Baikal water & 5.5 & 0.40 & 0.40 & 0.015 & 0.02 & 3.5 & 0.95 & 16.1 & 3.0 & 8.0 \\
Ratio: precipitation/water & 0.5 & 2.8 & 0.5 & 1.5 & 24 & 0.02 & 0.16 & 0.03 & 0.03 & \\
\hline
\end{tabular}

Table 3. Average ionic composition of summer precipitation in different areas of Lake Baikal.

\begin{tabular}{|c|c|c|c|c|c|c|c|c|c|c|}
\hline & $\mathbf{S O}_{4}{ }^{2-}$ & $\mathbf{N O}_{3}^{-}$ & $\mathbf{C l}^{-}$ & $\mathbf{P O}_{4}{ }^{3-}$ & $\mathbf{N H}_{4}{ }^{+}$ & $\mathbf{N a}^{+}$ & $\mathbf{K}^{+}$ & $\mathbf{C a}^{2+}$ & $\mathbf{M g}^{2+}$ & $\mathbf{p H}^{-}$ \\
\hline Listvyanka & 2.46 & 1.10 & 0.20 & 0.03 & 0.48 & 0.08 & 0.15 & 0.51 & 0.08 & 4.89 \\
B.Koty & 2.39 & 1.11 & 0.42 & 0.05 & 1.02 & 0.15 & 0.15 & 0.55 & 0.09 & 4.70 \\
Tankhoy & 1.55 & 0.82 & 0.26 & 0.03 & 0.43 & 0.15 & 0.26 & 0.42 & 0.07 & 5.09 \\
$\begin{array}{c}\text { Above the lake (by a } \\
\text { research vessel) }\end{array}$ & 2.01 & 1.39 & 0.38 & 0.04 & 0.21 & 1.47 & 0.18 & 0.79 & 0.07 & 5.47 \\
\hline
\end{tabular}

persists, to a lesser extent for nitrates, but to a greater extent for ammonium (Table 2). The total flow of them from the atmosphere to the water area in summer is higher due to an increase in the amount of precipitation in this season. At the same time, waves and wind mixing in summer leads to quicker dispersion of these compounds than under the ice coverand to more complicated relationships with phytoplankton.

Spatial differences in concentrations of biogenic elements in atmospheric precipitation over lake Baikal have not yet been studied, but from what is available today (Table 3), we can conclude that their concentrations in atmospheric precipitation are always higher than in the lake and, as a rule, higher than in river waters (Onishchuk et al., 2019).

To better understand the role of biogenic elements of atmospheric origin in the functioning of the lake ecosystem, special experiments are needed with individual precipitation on the lake, as well as analysis of nitrogen isotope ratios in precipitation and in food chains of the ecosystem.

\section{References}

Galazy G.I. 1984. Baikal v voprosah i otvetah [Baikal in questions and answers]. Irkutsk: East Siberian Publishing House. (in Russian)

Khodzher T.V., Sorokovikova L.M. 2007. The estimation of income of soluble substances from the atmosphere and with river inflow in Lake Baikal. Geografiya i Prirodnye Resursy [Geography and Natural Resources] 3: 185-190. (in Russian)

Kozhov M.M. 1962. Biologiya ozera Baikal [Biology of Lake Baikal]. Moscow: Academy of Sciences of USSR. (in Russian)

Obolkin V.A., Volkova E.A., Ohira S.I. et al. 2019. The role of atmospheric precipitation in the under-ice blooming of endemic dinoflagellate Gymnodinium baicalense var. minor Antipova in Lake Baikal. Limnology and Freshwater Biology 6: 345-352. DOI: 10.31951/2658-3518-2019-A-6-345

Onishchuk N.A. ,Netsvetaeva O.G., Tomberg I.V. et al. 2019. Seasonal dynamics of mineral forms of nitrogen in the rivers, snow cover and precipitation at the southwest coast of the Southern Baikal. Limnology and Freshwater Biology 3: 245-252. DOI: 10.31951/2658-3518-2019-A-3-245 